inOedia $\quad \begin{aligned} & \text { InMedia } \\ & \text { The French Journal of Media Studies }\end{aligned}$

6 | 2017

Fields of Dreams and Messages

The Politics of Discourse on the Fields of Dreams:

Political Messaging and the Mediated

Representation of Sports

Daniel Durbin and Yann Descamps

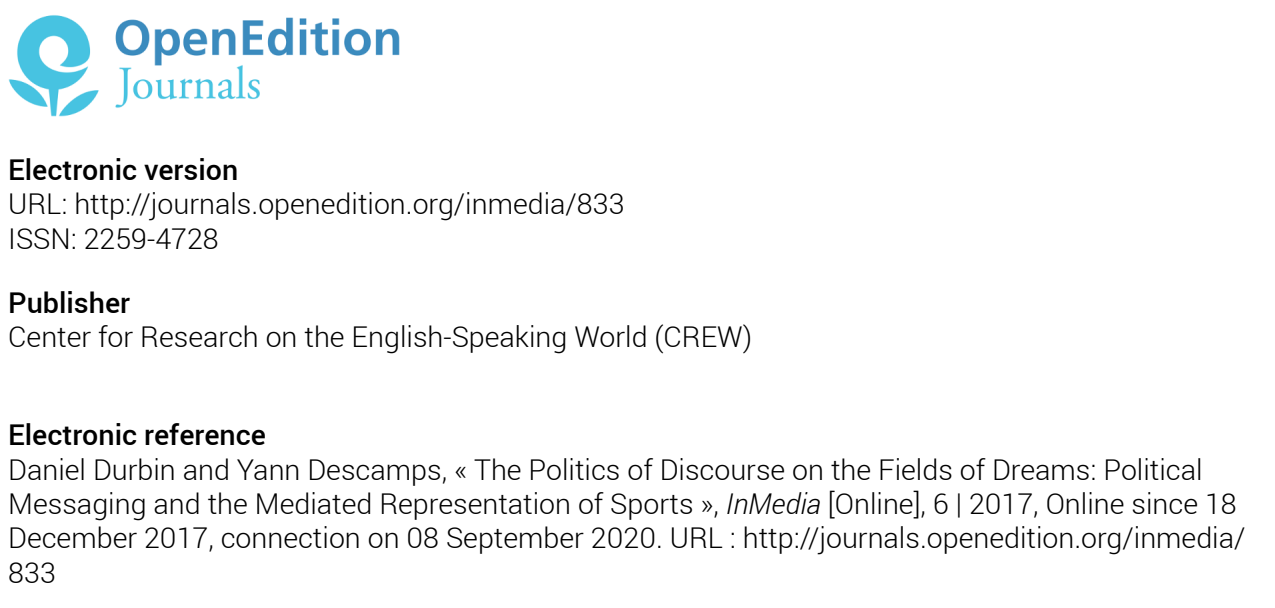

This text was automatically generated on 8 September 2020.

(C) InMedia 


\title{
The Politics of Discourse on the Fields of Dreams: Political Messaging and the Mediated Representation of Sports
}

\author{
Daniel Durbin and Yann Descamps
}

\section{Politics from the Field to the Audience}

1 In The Laws, Plato claimed that one of the chief ends of athletic contests was the composition and presentation of "speeches of commendation and reproof," narrative speeches drawn from the competition that could be used by the state to shape the values and actions of the citizenry. ${ }^{1}$ We know that many of the great rhetoricians of the day, including Gorgias, Lysias and Isocrates, used this platform to deliver often scathing political messages. ${ }^{2}$ Today, the mediated retelling of sports narratives continues to create political meaning from the events played out on the field. A significant body of sports scholarship has focused on this media-driven discourse and its impact on national and global politics.

2 From the use of the Olympics as a tool for propaganda-from Hitler's Germany to Putin's Russia-to the recent resurging political activism of African-American athletes and Donald Trump's ties with football star Tom Brady, ${ }^{3}$ the links between politics and sports have been well documented and widely studied. Sport is a global phenomenon whose impact goes far beyond mere entertainment. It expresses and, in performance, embodies moral and cultural values, and it can be a force for change as well as an instrument to control the masses. While sports have always had significant political implications, as the Olympics have shown throughout their history, ${ }^{4}$ the political dimension of sports spectacle plays out not only on the sports stage, but through media narratives which engage and, at times, shape political discourse. 
Indeed, the media do not simply broadcast or "show" sports events, they deconstruct the actions on the field or court and reconstructs them, representing, rather than showing, the competition. John Fiske argues that there is a difference between the "real" sporting event and "its mediated representation," ${ }^{5}$ and this mediated representation is of great significance, for sports take on additional meaning through this process. These meanings are further complicated by the wide array of media through which sports narratives are broadcast. With the explosion of social media, online streaming of sports content, reconstruction of sports in fantasy sports, pay-perview platforms as well as more traditional means for broadcasting sports narratives, sports stories intersect culture and politics in an ever-expanding number of ways. And, each of these media creates a slightly different message from the sports content, a message shaped by the medium on which it is expressed. In an era when sports leagues use transmedia storytelling to unfold their narratives and develop their brands, ${ }^{6}$ the media's role in both showing, shaping and using sports needs to be assessed. Even sports reporting goes well beyond reporting. As journalists and broadcasters represent sports events, they create morality plays, send messages, sell products and role models, and even deconstruct the sports space as well as the game itself. ${ }^{7}$ Sports are not only covered by news media such as newspapers, television, the radio or the Internet. They have also been seized by popular culture. Sports are represented in films, TV shows, and videogames, and enjoy strong ties with other media forms such as music. Beyond the cultural and social dimension of its impact on collective memory, the mediated representation of sports also has a political dimension that this special issue seeks to address.

\section{The Media as Political Platform for Governments and Athletes}

4 The mediated representation of sports is often political, especially when sports and their broadcasting are used for political purposes by role players such as governments and athletes. For instance, the Olympics and its broadcasting are brimming with political discourse. In 1938, filmmaker Leni Riefenstahl's Olympia started a trend in using sports and the media for political propaganda. Political messaging still can be found in the spectacle of opening ceremonies, during which host countries send strong cultural and political messages about themselves. ${ }^{8}$ These self-celebratory messages reach global audiences through television and the Internet. Olympic fanfares can be used to celebrate a country's values through the medium of music. John Williams' fanfares for the 1984 and 1996 Olympics embodied the American pastoral dream as much as the Olympic universal ideal. Recent Olympic bids include a strong political undertone, with politicians leading the way and sports diplomacy being at play through the host cities' communicating strategies on social media.

5 Athletes also use a variety of media to send their own messages and to shape their public image. Some use books and autobiographies to explore the political dimensions of their stories. For example, John Carlos wrote his autobiography to explain "the symbology" of what was then described as a "Black Power salute" at the 1968 Olympics, seeking to challenge his stereotyped representation by the media of that time. ${ }^{9}$ Other athletes have performed in commercials that send political messages. Among these, one might count Charles Barkley's "I am not a role model," LeBron James, Kevin Durant 
and Serena Williams' call for "equality," and top soccer players "showing racism the red card." Others express their political views through social media. NFL football player Colin Kaepernick uses Twitter and Instagram to give substance to his symbolic protest of the American national anthem and to extend his discourse on issues of race, politics and violence. Some former athletes host talk shows and podcasts to be free to discuss subjects they were not supposed to address as athletes or before the news media. Former NBA player Chris Webber discusses politics at length in his podcast Fearless or Insane with Chris Webber. Moreover, the rise of new media has given birth to new challenges. The links between social media and sports have garnered a great deal of scholarly attention over the past few years, mostly through the prism of fan engagement. ${ }^{10}$ However, other issues related to social media and sports have emerged recently. The use of social media by athletes as a tool for self-representation is not devoid of a political dimension, especially in the case of athletes who were underrepresented in the media and now send political messages through these new platforms. Also, social media represent a new branding challenge for the sports world. Indeed, sexism and racism are some of the scourges that social media have revealed-or exposed more blatantly. ${ }^{11}$ Last, new issues have appeared regarding the status of athletes, and especially student-athletes, as representatives of their university's brand -a role that can sometimes come into conflict with their identities as citizens entitled to their own political views.

\section{The Politics of Representation in the Media and Popular Culture}

6 Even when athletes and governments do not explicitly use the media to political ends, the mediated representation of sports has a latent political undertone. Indeed, the way sporting events are announced, filmed, broadcast, and the way athletes are portrayed or pictured can be politically relevant. Among the early scholars to focus on this dimension of sport, Lawrence Wenner explored the political implications of the mediated representation of sports..$^{12} \mathrm{He}$ underlined how the Super Bowl was constructed as an American spectacle. ${ }^{13}$ Not only does this event become a representation of the American culture, but it can also be turned into a tool of propaganda and soft power for the United States on the global sports and media stage. Another early scholar, Thomas Farrell, wrote of the Olympics as a platform for promoting a rhetorical and political vision of national identity and the challenges nations faced when athletic performance did not live up to the political vision created through media. ${ }^{14}$ More recently, some radio shows such as Colin Cowherd's The Herd have developed cultural discourse with a political undertone. Most importantly, the mediated representation of sports allows us to address issues of gender and minority representations. John Fiske proposes that discourse was "a terrain of struggle" in the media. ${ }^{15}$ Indeed, the visual and verbal discourses articulated through sports in the media do reflect this element of struggle, as they are plagued with issues of sexism and racism. ${ }^{16}$ In sports as much as in the news, identities can be framed through words and images, thus influencing the collective imagination and having a political impact. ${ }^{17}$

7 From films to TV shows, music and videogames, sports have also been portrayed in popular culture, and their representation is not limited to the reenactment of athletic performances. Sport is used as a means to address other subjects such as the definition 
of manhood, the importance of moral values, or the construction of identities. Aaron Baker emphasizes the political dimension of sports in films when he writes that "[they] contribute to the contested process of defining social identities." 18 Todd Boyd has examined the strong links between basketball and hip-hop music, and has shown that such links have a strong political undertone. ${ }^{19}$ Last, David Leonard has brought to light the latent racism that can be found in the representation of African-Americans in TV shows and videogames. ${ }^{20}$

\section{The (Political) Game behind the (Mediated) Game}

The rise of the mediated representation of sports has turned sports into a global phenomenon and a multibillion-dollar industry. More importantly, it has considerably raised the impact of sports on society and its collective imagination. Sports contribute both to bringing about change and preserving the status quo when it comes to defining identities or building communities. More precisely, the mediated representation of sports motivates audiences to seek change or hold to the status quo. Therefore, it has political consequences.

9 In his article entitled "Longshot: Sports Celebrity Diplomacy in the Democratic People's Republic of Korea," Michael Park explores sport as an instrument of American soft power, referring to Nye's work and references to Michael Jordan as a soft power figure. Informed by Cooper's theoretical perspective on celebrity diplomacy, Park's work extends the celebrity diplomacy discourse into the area of sports celebrities and explores the figure of the celebrity athlete as an instrument of diplomacy. He also expands the discourse on celebrity athletes as antidiplomats, and studies Dennis Rodman's "basketball diplomacy" efforts in North Korea to examine the power celebrity athletes can have on fostering engagement with other governments. His research underlines the critical part played by the media - old and new - in the making of celebrities, the building of myths, and the rise of American soft power. As Park shows, while basketball can be used as a tool for conveying American soft power through the NBA, Michael Jordan, or Dennis Rodman - it can also be used by the North Korean regime as a legitimization of the government. The North Korean media accounts of Rodman's basketball diplomacy underlines the potential limitations of celebrity athlete diplomacy and opens on cautious conclusions when celebrity athletes are used as instruments of engagement. Sport has some diplomatic value as it can start a dialogue between nations. However, the media is key here, as it can help influence the public's perception of an event, culture, and country, and thus help bridge the cultural and political gap between nations - or widen it.

In "Coubertin's Music: Culture, Class, and the Failure of the Olympic Project," Nicholas Attfield focuses on the importance of music in Coubertin's Olympic project. He highlights how Coubertin envisioned sport as a signifying cultural practice, and how music could contribute to channeling, promoting and celebrating the spirit of the Modern Olympics - along with its socio-political message - through aesthetics. Bringing more attention to music and "eurhythmy" in the wake of Brown's work, Attfield shows that Coubertin envisioned the Olympics as a potential aesthetic experience comparable to "total artwork." However, by trying to make his Olympic humanism a modern and resounding reality, he failed to acknowledge issues of culture and class, as well as the political use of both music and the Olympics to serve not his 
Republican ideas but nationalism in the case of the 1936 Olympics. The author underlines the part played by music in the signifying multimedia spectacle of the Olympics, and its potential political dimension, when aesthetics is used to promote host countries instead of the Olympic project itself.

In her article entitled "Broke Ballers: The Mediated World of Football and Finance," Courtney Cox examines the first two seasons of TV show Ballers in terms of the sportsmedia complex, player identity, and the embedded nature of culture and finance using qualitative content analysis, as well as referring to Wodak's work on characters as social actors. Drawing a parallel between sports films and scripted sports television, while questioning where the latter fits in the interactions between media, sports and society highlighted in Wenner's Transactional model, Cox argues that TV shows can reflect society - in the creation, production and construction of certain social conditions and/or the restoration, justification, reproduction, transformation or destruction of a certain social status quo. She shows that Ballers examine and reproduce certain social practices, reinforcing ideas about race, gender, class and the world of finance. In a nutshell, the show tends to relay stereotypes about black athletic masculinity without really deconstructing them. It also stages the media's influence over the sporting world - from television shows and analysts to Twitter and videogames - and their failure to confront issues of inequity. This article examines the political dimension of sports TV shows when these deal with issues of race, class and gender.

In "Sport in Films: Symbolism versus Verismo. A France-United States Comparative Analysis," Valérie Bonnet tackles sports films and their cultural and political dimension, mostly through the projection they offer of the nation which produces them. Indeed, after having questioned the social existence of the sports film genre and defined its attributes and properties, mainly using Altman's definition of a film genre, the author studies how both nations - France and the United States - project themselves through sports films. She goes on to highlight two very different film industries and productions as regards sport and its use in films. Indeed, the part played by sports is not the same: while it is an entry point in American cinema, a way to promote American values and sell the (Athletic) American Dream, it is somewhat of an element of contextualization in French cinema, as well as an opportunity to criticize the sports environment. In both instances, sports films do have a strong political dimension: they reflect social issues of their times and allow audiences to embrace either a representation of American society as filmmakers would have it perceived or an image of sport as despicable or politically feckless. The paper also broaches the subject of the influence of other media on film productions, as television broadcasting of sporting events and sports reporting in general tend to develop more storytelling than sports films do in the French context. Bonnet argues that the French audience looks for a filmed sports contest, while the American audience is more attached to the symbolic and cultural dimension of sports, thus opposing a French strategy of verismo to American symbolism through sports films - reflecting two different approaches to sports in the media, as well as the political dimension of sports and the political use of sports in films.

13 At a crucial time in the relation between sports and the media, with the renewal of athletes' activism and the new challenges brought on by social media, this issue offers various articles that seek to deconstruct the mediated representation of sports through 
the prism of politics. From sports diplomacy and its media coverage to the links between music, politics and the Olympics, and the political dimension of sports TV shows and sports films from different cultures, it aims to explore how sports and the way they are represented, convey both straightforward and incidental political messages.

This media file cannot be displayed. Please refer to the online document http:// journals.openedition.org/inmedia/833

Baker, Aaron. Contesting Identities: Sport in American Film. Chicago: University of Illinois Press, 2003.

Blociszewski, Jacques. Le match de football télévisé. Rennes: Éditions Apogée, 2007.

Boyd, Todd. Young, Black, Rich, and Famous: The Rise of the NBA, the Hip-Hop Invasion, and the Transformation of American Culture. Lincoln: University of Nebraska Press, 2003.

Carlisle Duncan, Margaret, Messner, Michael A. “The Media Image of Sport and Gender.” In MediaSport, edited by Lawrence A. Wenner, 170-185.London: Routledge, 1998.

Carlos, John, with Zirin, Dave. The John Carlos Story: The Sports Moment That Changed the World. Chicago: Haymarket Books, 2011.

Consalvo, Mia, et al. eds. Sports Videogames. New York: Routledge, 2013.

Davies, Laurel R., Harris, Othello, "Race and Ethnicity in US Sports Media." In MediaSport, edited by Lawrence A. Wenner, 154-169. London: Routledge, 1998.

Durbin, Daniel. “Trumporable Tom Brady”. US News. <accessed on February 5, 2017>

Farrell, Thomas B. "Media Rhetoric as Social Drama: The Winter Olympics of 1984." Critical Studies in Mass Communication. 6 (1989), 158-182.

Farrington, Neil, et. al. Sport, Racism and Social Media. London: Routledge, 2014.

Fernandez Peña, Emilio, et al. eds. An Olympic Mosaic: Multidisciplinary Research and Dissemination of Olympic Studies. Barcelona: Centre d'Estudis Olimpics, 2011.

Fink, Janet S., Kensicki, Linda Jean. “An Imperceptible Difference: Visual and Textual Constructions of Femininity in Sports Illustrated and Sports Illustrated for Women." Mass Communication and Society, Vol. 5, $\mathrm{n}^{\circ} 3$ (August 2002): 317-340.

Fiske, John. Media Matters: Race and Gender in U.S. Politics. Minneapolis: University of Minnesota Press, 1999.

Fiske, John. Television Culture. New York: Routledge, 2011 (1987).

Frau-Meigs, Divina. Médiamorphoses américaines. Dans un espace privé unique au monde. Paris: Economica, 2001.

Hall, Stuart ed. Representation: Cultural Representations and Signifying Practices. London: The Open University, 1997.

Humbert, Henri, “La presse sportive française et l'encouragement à l'hégémonie masculine (1900-1970)." In Sport et Genre. Vol. 2: Excellence féminine et masculinité hégémonique, directed by Liotard, Philippe, Terret, Thierry, 241-262. Paris: L'Harmattan, 2005.

Jenkins, Henry. Convergence Culture: Where Old and New Media Collide. New York: New York University Press, 2006. 
Kane, Mary Jo, Jefferson Lensky, Helen, "Media Treatment of Female Athletes: Issues of Gender and Sexualities." In MediaSport, edited by Lawrence A. Wenner, 186-201. London: Routledge, 1998. Lavelle, Katherine L. “'One of These Things Is Not Like the Others': Linguistic Representations of Yao Ming in NBA Game Commentary." International Journal of Sport Communication (2011): 50-69.

Leconte, Bernard. "Retransmission sportives et énonciation televisuelle: quand la télévision, sous couvert de reportage sportif, parle de tout autre chose." In Montrer le sport. Photographie, cinéma, télévision, directed by Veray, Laurent, Simonet, Pierre, 203-210. Paris: INSEP, 2000.

Leonard, David. “'Live in Your World, Play in Ours': Race, Video Games, and Consuming the Others." Studies in Media \& Information Literacy Education, Volume 3, Issue 4 (November 2003): 1-9. DOI: $10.3138 / \operatorname{sim} .3 .4 .002$

Leonard, David J., Guerrero, Lisa A. eds. African Americans on Television: Race-ing for Ratings. Santa Barbara, California: Praeger, 2013.

Milza, Pierre, et al.dir.Le pouvoir des anneaux. Les Jeux olympiques à la lumière de la politique, 1896-2004. Paris: Vuibert, 2004.

Plato. The Laws. London: Penguin Classics, 2005.

Riefenstahl, Leni. Olympia. The Complete Original Version [DVD]. Pathfinder, 2006 (1938).

Spivey, Nigel. The Ancient Olympics. Oxford: Oxford University Press, 2012.

Vigarello, Georges. "Le marathon entre bitume et écran.” Communications, 67 (1998): 211-215. DOI: 10.3406/comm.1998.2026

Wenner, Lawrence A. ed. Media, Sports, and Society. Newbury Park: Sage Publications, 1989.

Wenner, Lawrence A. "The Super Bowl Pregame Show: Cultural Fantasies and Political Subtext." In Media, Sports, and Society, edited by Lawrence A. Wenner, 157-179. Newbury Park: Sage Publications, 1989.

Wenner, Lawrence A. ed. MediaSport. London: Routledge, 1998.

\section{ENDNOTES}

1. Plato, The Laws (London: Penguin Classics, 2005), 227.

2. Nigel Spivey, The Ancient Olympics (Oxford: Oxford University Press, 2012), 191.

3. Daniel Durbin, “Trumporable Tom Brady," US News. <accessed on February 5, 2017>

4. Pierre Milza, et al. dir., Le pouvoir des anneaux. Les Jeuxolympiques à la lumière de la politique, 1896-2004 (Paris : Vuibert, 2004).

5. John Fiske, Television Culture (New York: Routledge, 2011 (1987)), 14.

6. See Henry Jenkins' use of the concept to tackle the Matrix and its story unfolding through different media.

Henry Jenkins, Convergence Culture: Where old and New Media Collide (New York: New York University Press, 2006), 98.

7. Jacques Blociszewski, Le match de football télévisé (Rennes : Éditions Apogée, 2007) ; Bernard Leconte, "Retransmission sportives et énonciationtélévisuelle : quand la télévision, sous couvert 
de reportage sportif, parle de tout autre chose," In Montrer le sport. Photographie, cinéma, télévision, directed by Laurent Veray, Pierre Simonet (Paris : INSEP, 2000), 203-210; Georges Vigarello, "Le marathon entre bitume et écran," Communications, 67 (1998) : 211-215. DOI : 10.3406/comm. 1998.2026

8. Leni Riefenstahl, Olympia. The Complete Original Version [DVD] (Pathfinder, 2006 (1938)).

9. John Carlos, with Dave Zirin, The John Carlos Story: The Sports Moment That Changed the World (Chicago: Haymarket Books, 2011), 110.

10. Emilio Fernandez Peña, et al. eds, An Olympic Mosaic: Multidisciplinary Research and Dissemination of Olympic Studies (Barcelona: Centre d'EstudisOlimpics, 2011).

11. Neil Farrington, et al., Sport, Racism and Social Media (London: Routledge, 2014).

12. Lawrence A. Wennered, Media, Sports, and Society (Newbury Park: Sage Publications, 1989);

Lawrence A. Wennered, MediaSport (London: Routledge, 1998).

13. Lawrence A. Wenner, "The Super Bowl Pregame Show: Cultural Fantasies and Political Subtext," In Wenner, Media, Sports, and Society, 157-179.

14. Thomas B. Farrell, "Media Rhetoric as Social Drama: The Winter Olympics of 1984," Critical Studies in Mass Communication, 6 (1989), 158-182.

15. John Fiske, Media Matters: Race and Gender in U.S. Politics (Minneapolis: University of Minnesota Press, 1999), 5.

16. Margaret Carlisle Duncan, Michael A. Messner, "The Media Image of Sport and Gender," In Wenner, MediaSport, 170-185; Laurel R. Davies, Othello Harris, "Race and Ethnicity in US Sports Media," In Wenner, MediaSport, 154-169; Janet S. Fink, Linda Jean Kensicki, “An Imperceptible Difference: Visual and Textual Constructions of Femininity in Sports Illustrated and Sports Illustrated for Women," Mass Communication and Society, Vol. 5, n 3 (August 2002): 317-340; Henri Humbert, "La presse sportive française et l'encouragement à l'hégémonie masculine (1900-1970)," In Sport et Genre. Vol. 2: Excellence féminine et masculinitéhégémonique, directed by Philippe Liotard, Thierry Terret (Paris : L'Harmattan, 2005), 241-262; Mary Jo Kane, Helen Jefferson Lensky, "Media Treatment of Female Athletes: Issues of Gender and Sexualities," In Wenner, MediaSport, 186-201; Katherine L. Lavelle, “'One of These Things Is Not Like the Others': Linguistic Representations of Yao Ming in NBA Game Commentary," International Journal of Sport Communication (2011): 50-69.

17. See Divina Frau-Meigs' use of the media's framing of identities and its impact on the public's perception. Divina Frau-Meigs, Médiamorphoses américaines. Dans un espaceprivé unique au monde (Paris : Economica, 2001), 97-106.

18. Aaron Baker, Contesting Identities: Sport in American Film (Chicago: University of Illinois Press, 2003), 2.

19. Todd Boyd, Young, Black, Rich, and Famous: The Rise of the NBA, the Hip-Hop Invasion, and the Transformation of American Culture (Lincoln: University of Nebraska Press, 2003).

20. David Leonard, “Live in Your World, Play in Ours': Race, Video Games, and Consuming the Others," Studies in Media \& Information Literacy Education, Volume 3, Issue 4 (November 2003): 1-9. DOI: 10.3138/sim.3.4.002; David J. Leonard, Lisa A. Guerrero eds, African Americans on Television: Race-ing for Ratings (Santa Barbara, California: Praeger, 2013).

\section{INDEX}

Mots-clés: Sports, Media, Popular Culture, Discourse, Politics, Representation 


\section{AUTHORS}

\section{DANIEL DURBIN}

Annenberg Institute of Sports, Media and Society, University of Southern California

Pr. Daniel Durbin is the Director of the Annenberg Institute of Sports, Media and Society at the University of Southern California. He teaches courses across a broad variety of subjects, including sports, sports media, the social and cultural impact of sports, social movements, classical and contemporary theories of rhetoric, and fashion and media. He has published articles in sports, popular culture, and sports media studies.

\section{YANN DESCAMPS}

PhD, Université Sorbonne Nouvelle - Paris 3

Yann Descamps is a PhD in American studies from the Université Sorbonne Nouvelle - Paris 3. His thesis dissertation deals with the importance of basketball in African-American popular culture, as well as its representation in the American media.descampsyann@yahoo.fr 